\title{
Finding and Using a Co-packer ${ }^{1}$
}

\section{Alison O'Donoughue, Wendi Jennings, and Soohyoun Ahn²}

This factsheet is one in the "Food Entrepreneurship in Florida" series, which assists beginning and established food entrepreneurs by providing them information on topics highly relevant to starting and running a food business, including regulations, safety, labeling, processing, and marketing. This series serves as a useful guide to help run successful foodrelated business.

You are a home-based cottage food operator who is now considering larger-scale commercial production to make bigger profits. Or you are currently operating out of a commercial kitchen and recently got a contract with a big, national chain store to carry your products. Whatever stage of food business you are currently in, you will reach a point where you will need high-volume production. At this point, running your operation out of your home kitchen or renting a commercial kitchen might not be the best option, because the facility size or availability might not accommodate your needs. You can build your own facility if you have capital; however, if you have limited funds or if you think you are not ready to hire staff and operate new equipment for your production, then hiring a co-packer can be a great option. This factsheet will provide a brief overview on the definition of co-packers, advantages and disadvantages of using a co-packer, and the list of things you need to consider when you hire and work with a co-packer.

\section{What is a co-packer?}

A contract packager, commonly called a co-packer, is a manufacturer that will produce, package, and/or label a product for clients. A co-packer is often a manufacturer that has excess processing capacity and processes clients' product under a private label for a fee. In addition to manufacturing, packaging, and labeling, some co-packers also offer services in certifications, storage, and distribution.

\section{What are the advantages of using a co-packer?}

(1) Reduced financial risk: There are occasions that may warrant outsourcing to a co-packer. For example, your business may have outgrown the space you have or will require the purchase of additional equipment. You might need to build your own facility or hire more employees. This expansion of business can be costly and pose great financial risk. By using a co-packer, you can produce products of a predetermined quantity and test these products in a market without investing large sums of money in building, equipment, and employees. Once your product has proven successful in the market, you can invest in your own equipment or facility. This approach significantly reduces financial risk for small food manufacturers with limited resources.

1. This document is FSHN20-35, one of a series of the Food Science and Human Nutrition Department, UF/IFAS Extension. Original publication date April 2020. Visit the EDIS website at https://edis.ifas.ufl.edu for the currently supported version of this publication. This article was funded by the United States Department of Agriculture-National Institute of Food Agriculture (USDA-NIFA) Grant \#2016-70020-25784.

2. Alison O'Donoughue, Extension program assistant; Wendi Jennings; former Extension program assistant; and Soohyoun Ahn, assistant professor, Food Science and Human Nutrition Department; UF/IFAS Extension, Gainesville, FL 32611.

The Institute of Food and Agricultural Sciences (IFAS) is an Equal Opportunity Institution authorized to provide research, educational information and other services

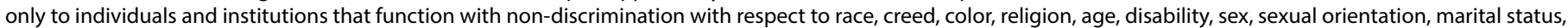

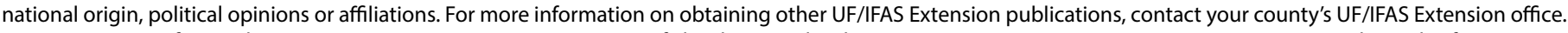
U.S. Department of Agriculture, UF/IFAS Extension Service, University of Florida, IFAS, Florida A \& M University Cooperative Extension Program, and Boards of County Commissioners Cooperating. Nick T. Place, dean for UF/IFAS Extension. 
(2) Professional assistance and resources: Because co-packers are established food processors with years of business experience, most co-packers are familiar with food regulatory requirements, shipping and distribution, and other business needs. Some co-packers have in-house staff and offer services for their clients such as product testing, nutritional labeling, product formulation, ingredient substitution, product design suggestion, and other product development services. Additionally, many co-packers have food industry contacts and sources, and they can direct you to appropriate professionals who can help with any specific questions or issues you might have during the production. These resources can be especially valuable for new food entrepreneurs.

(3) Saving time and space: Operating your own production facility and overseeing the production requires a significant time commitment. By working with co-packers, you can devote more time to marketing your products to potential customers. Many co-packers also have proper facilities that can store your ingredients and finished products, reducing costs associated with storage.

\section{(4) Facilitating compliance with regulatory requirements:}

Food regulations under local, state, and federal laws are complex, and complying with all aspects of food regulations can be overwhelming, costly, and time-consuming for beginning manufacturers. Many co-packers have obtained the necessary licenses and permits, have appropriate waste disposal systems in place, and have completed trainings or certifications required for their manufacturing operation. By working with a co-packer, you can save money and time to meet regulatory requirements.

\section{What are the disadvantages of using a co-packer?}

One of the disadvantages of using a co-packer is a loss of control over your product and its manufacturing. You will also be subject to the co-packer's production schedule. Most co-packers do not require a customer to be present during the production except the first run. This can lead to future production runs that the customer might not be fully satisfied with. If there is any dispute or disagreement between customers and co-packers, it can delay production and distribution of products.

A co-packer often works with multiple customers for a similar type of products. Because you need to share sensitive product information with your co-packer, including ingredients, formulations, and product specifications, confidentiality can be a potential problem. If this is the case, you might consider obtaining a confidentiality agreement with the co-packer to protect sensitive information about your product.

\section{How should I select a co-packer?}

Because a co-packer can run full scope of production, from ingredient receiving and manufacturing to labeling and packaging (and even shipping to your customers), it is critical to choose the best co-packer for your food product. Before meeting with the co-packer, prepare a detailed business plan. This business plan should include your business goals and objectives, product description, marketing plan, and financial plan (Ahn et al. 2017). Writing a business plan will give you an opportunity to review your business goals and marketing plan and help you assess the appropriate size of the order. Reviewing your business goals will facilitate finding a co-packer who has the same business mindset and can meet your specific needs. In addition, write detailed process instructions with specifications for ingredients, packaging, and labeling as well as any relevant regulatory requirements. It is important to have a well-developed idea of what you want for your product before meeting with potential co-packers.

If you have identified several potential co-packers, bring your process instructions and business plan to your first meeting. It will help to create a checklist or a list of questions for the meeting. Some of the questions you should ask include:

\section{What size and type of packaging am I interested in for my product?}

Certain co-packers may only specialize in one type of food or container size. For example, if the product you are looking to produce is a hot sauce, you would need a co-packer who can package liquids into small bottles. You might need to know if they can hot fill or are capable of aseptic filling and other specific production needs unique to your product.

\section{What is the minimum production the co-packer is willing to do?}

In general, larger co-packers will only produce greater amounts of a product, whereas smaller co-packers offer smaller production runs. 


\section{What is the specific cost for processing and handling your product?}

Be sure to specifically ask the price for the co-packer's service. You can ask if they can offer a guaranteed price for a year or other certain terms. Make sure there are no hidden fees.

\section{Can the co-packer produce your product the way you want} it to be made?

If your product requires special preparation techniques, ingredients, or storage, ensure that the co-packer can follow your specifications.

\section{If applicable, can the co-packer provide the certifications you need?}

If you want your product to be Kosher, Halal, organic, gluten-free, or non-GMO certified, you will need to find a co-packer who can provide those certifications.

\section{Will this co-packer be able to assist in product design and development?}

If your product is not quite ready for the shelf, you can benefit from product development services. Ask if the copacker has staff or offers services for product development, including product testing, nutritional labeling, product formulation, ingredient substitution, and product design. Using the co-packer's in-house product development services can save considerable time and costs.

\section{What is the co-packer's safety and quality policy?}

Touring the co-packer's facility can answer many production-related questions as well as give insight to the cleanliness, safety, and potential hazards of the facility. You can also ask for the most recent inspection report and their food safety systems (e.g., Preventive Controls, HACCP) or quality control systems, if they have any. A co-packer should have a list of clients. If possible, contact a current client to discuss their experiences, and try one of the products manufactured by the potential co-packer.

\section{What is my production timeline?}

Production schedule is an important factor to consider when you work with a co-packer. You should carefully communicate with the co-packer on scheduling so you will not be stuck in a production hold, which could jeopardize your business. Many co-packers ask their clients to confirm the production at least a month or more in advance. You might need to ask how the co-packer handles "emergency" product demands (e.g., holiday season) and if they have the equipment/personnel resources to handle unexpected demands, and at what cost.

\section{Will the co-packer handle growing demands in the future?}

When you meet a co-packer, you also need to think about future needs. Early in the production, you may need only small production runs, but once your business grows, you may need more volume. You have to make sure this copacker can accommodate high-volume orders in the future.

\section{Can the co-packer provide assistance with ordering and storage of ingredients and supplies?}

One of the main reasons to work with a co-packer is a lack of facilities. You may need storage space for your ingredients, supplies, or finished products. Ask potential co-packers if they can provide storage space. Also ask the co-packer if they can directly order ingredients and supplies or if you need to order and ship them to the co-packer. Some co-packers can introduce you to brokers or distributors that you can work with. Other factors you need to consider are:

- A confidentiality agreement

- The financial stability of the co-packer

- The location of the co-packer

Once you have identified a co-packer for your product, you should write a contract to ensure your product is manufactured according to your specifications in a timely manner. In general, a contract should contain the following elements:

- The parties involved

- The quantity of product to be produced

- The quality of product to be produced (including specifications you require)

- The timeline for the production to be completed

- The price to be paid (including payment method and when the payment is due)

It is recommended to have your attorney and potentially your accountant review the contact before you sign. Your attorney can ensure that the terms are satisfactory and that you are legally and financially protected if any problem occurs. 


\section{Where can I find a co-packer near}

\section{me?}

Having a co-packer that is geographically close to you allows you to have a more active role in the production. However, it is not uncommon for a food entrepreneur to work with co-packers in other states, especially if your product has special needs (e.g., specific equipment, certifications, etc.). You can get information about co-packers by talking to other food entrepreneurs. State and national association meetings, food shows, and trade shows can also be good places to meet co-packers. Other good resources include food industry trade publications and directories, because many specialized co-packers advertise through them. If you look for more local co-packers, university Extension offices can also be a resource for locating a co-packer.

There are several websites that provide the national copacker directory:

- Specialty Food Co-Packers Directory: http://www. specialtyfoodcopackers.com/The-Directory.html

- The Association for Contract Packagers \& Manufacturers: https://www.contractpackaging.org (select Member Directory at the tab menu)

Below is a noncomprehensive list of co-packers located in Florida and Georgia. The list is simply for information purposes, and it does not constitute or imply an endorsement or recommendation by the authors or UF/IFAS Extension. For details, contact the company directly.

\section{Florida}

\section{All Wrapped Up}

3714 Northwest $16^{\text {th }} \mathrm{St}$

Ft. Lauderdale, FL 33311

Phone: (800) 891-2194

Fax: (954) 587-2144

Email: info@allwrappedup-gifts.com

Website: http://www.allwrappedup-gifts.com/

Processing: chocolate, other candy and snacks, specialty food packaging

\section{Al-Rite Bottled Ideas \\ 18524 NW 2nd Ave \\ Miami, FL 33179}

Phone: (305) 652-2540

Fax: (305) 652-4478

Email: info@al-rite.com

Website: http://www.al-rite.com

Processing: liquid beverages, concentrates, sauces, teas, drink mixes
Ashlynn's Gourmet

22105 US Hwy $19 \mathrm{~N}$

Clearwater, FL 33765

Phone: (727) 687-3267

Email: info@ashlynnsgourmet.com

https://www.ashlynnsgourmet.com/co-packing-services/

Processing: sauces

\section{Azure Water}

1903 Greenleaf Lane

Leesburg, FL 34748

Phone: (352) 728-5646

Email: sales@azurewater.com

https://azurewater.com/

Processing: bottled water

Beneficial Blends, LLC

5505 Johns Rd., Ste. 704

Tampa, FL 33634

Phone: (800) 230-5952

http://beneficialblends.com/

Processing: liquid and semiliquid products

Best Brand Bottlers

$662019^{\text {th }}$ Street East

Sarasota, FL 34243

Phone: (943) 755-1941

Fax: (943) 755-1213

Email: office@bestbrandbottlers.com

https://www.bestbrandbottlers.com/

Processing: salad dressings, marinades, BBQ sauces, pasta sauces, hot sauces and cocktail sauces

Beverage Corporation International, Inc.

$3505 \mathrm{NW} 107^{\text {th }} \mathrm{St}$

Miami, FL 33167

Phone: (786) 413-0530

http://bcibeverages.com/

Processing: sodas, juices, waters, energy drinks

Criollos Food, Inc.

3675 NW $67^{\text {th }}$ Ave

Miami, FL 33147

Phone: (305) 691-7993

https://www.criollosfoodusa.com/

Processing: dry beans, peas, wheat, flours, cornmeal 
Endorphin Farms, Inc.

3255 Parker Drive

St. Augustine, FL 32084

Phone: (904) 824-2006

Fax: (904) 824-4014

http://www.bottle-my-sauce.com

Processing: sauces

\section{G. S. Gelato}

1785 FIM Boulevard

Fort Walton Beach, FL 32547

Phone: (850) 243-5455

Fax: (850) 243-5443

Email: info@gsgelato.com

http://www.gsgelato.com

Processing: gelato, sorbet, desserts

\section{HぬH Products Company}

6600 Magnolia Homes Road

Orlando, FL 32810

Phone: (800) 678-8448

Email: info@hhproductscompany.com

https://www.hhproductscompany.com/contract-packaging/

Processing: beverage, juice concentrates, syrups

\section{House Autry}

2732 Hibiscus Drive

Edgewater, FL 32141

Phone: (386) 428-5833

https://www.house-autry.com/pages/private-label

Processing: dry blends (seasonings, marinades, sauces)

IPAC Inc. (International Packaging of Authentic Cuisine) 1270 Belle Avenue, Unit 115

Winter Springs, FL 32708

Phone: (407) 699-7507

Fax: (407) 699-7548

http://www.copack.com/about-us.php

Processing: sauces/salsas, soups, dressings, cocktail mixers

\section{Kitchen Fusions}

$634982^{\text {nd }}$ Ave N

Pinellas Park, FL 33781

Phone: (727) 546-3444

Fax: (727) 934-9967

Email: info@mycopacker.com

http://www.mycopacker.com/about-us/

Processing: sauces, dips (dry blending only)
Marina Foods, Inc.

$11125 \mathrm{NW} 124^{\text {th }} \mathrm{St}$

Medley, FL 33178

Phone: (786) 888-0129

Fax: (786) 888-0134

Email: info@marinafoods.com

https://www.marinafoods.com/

Processing: cooking oils, salad dressings, sauces

\section{Old Meeting House Ice Cream}

4004 South MacDill Avenue

Tampa, FL 33611

Phone: (813) 248-3151, Ext 110

Fax: (813) 248-6254

http://www.omhicecream.com/index-2.html

Processing: ice cream, soy cream, gluten free

Palmetto Canning Co. Inc.

3601 US Hwy 41

Palmetto, FL 34221

Phone: (941) 722-1100

Email: pcrbaggs@tampabay.rr.com

http://www.palmettocanning.com

Processing: dietary supplements, marinades, sauces,

dressings, cooking wines, jellies and marmalades

Pals Group, Inc. (Lakay)

$5761 \mathrm{NW} 37^{\text {th }}$ Avenue, Suite 101

Miami, FL 33142

Phone: (305) 638-7355

Fax: (305) 638-8655

https://lakayfood.com/index.html

Processing: grains, condiments, beverages, canned goods, oils, juices, sauces

\section{The Sauceology Group}

$1422160^{\text {th }}$ Street North

Clearwater, FL 33760

Phone: (727) 599-0631

https://thesauceologygroup.com/

Processing: sauces, spice blends, rubs, salsas, dressings, marinades

Southeast Bottling \& Beverage

15340 Citrus Country Drive

Dade City, FL 33523

Phone: (352) 567-2200

Fax: (352) 567-2257

https://southeast-bottling.com/

Processing: water, juices, teas, energy drinks, kosher,

organic 


\section{Stage Coach Sauces}

$806 \mathrm{~N}$ Beach Street

Daytona Beach, FL 32114

Phone: (386) 328-6330

Email:info@stagecoachsauces.com

http://www.stagecoachsauces.com

Processing: sauces, condiments, dressing, syrups

\section{St. Armands Baking Company}

$281159^{\text {th }}$ Avenue Drive East

Bradenton, FL 34203

Phone: (941) 753-7494

https://www.starbake.com/co-packing

Processing: bread and roll bakery products

\section{Tiller Foods}

3803 E Columbus Drive

Tampa, FL 33605

Phone: (813) 739-2111

http://www.tillerfoods.com

Processing: yogurt, sour cream, cream, buttermilk, whipping cream, ice cream and dairy mixes, dessert mixes,

coffee creamer, Pareve (Parve) and Kosher

\section{Williams \& Bennett Fine Foods}

1815 Cypress Lake Dr

Orlando, FL 32837

Phone: (561) 276-9007

Email: orders@lasolabrands.com

http://williamsandbennett.com/

Processing: candies, chocolates

\section{Georgia}

\section{Braswell's Foods, Inc.}

$226 \mathrm{~N}$ Zetterower Ave

Statesboro, GA 30458

Phone: (800) 673-9388

Email: customerservice@braswells.com

https://braswells.com/

https://s3.amazonaws.com/cdn.braswells.com/downloads/

Braswell-Catalog-8.pdf

Processing: jams, jellies, dressings, marinades, sauces,

honeys, toppings

\section{Country Ranch Foods}

1460 Field Park Circle

Marietta, GA 30066

Phone: (770) 792-9000/(888) 653-5550

Fax: (770) 792-8000

http://www.countryranchfoods.com/privatelabel.html
Processing: kettle items (gravies, sauces, soups, stews, chitterlings, broths), oven items (baked, dried, smoked and steamed chicken, roast, sausage, turkey), raw items (bulk sausage, sausage patties and links)

\section{Custom Beverage Concepts}

344 Golf Course Rd

Tallapoosa, GA 30176

Phone: (770) 574-9899

Email: caseyb@custombeverageconcepts.com

http://custombev.wpengine.com/our-products/

private-label-products/

Processing: hot and cold beverages, sweetener, creamer, protein shakes

DeD Foods, Inc.

$37154^{\text {th }}$ Avenue

Columbus, GA 31904

Phone: (706) 322-4507

Email: orders@foysbbq.com

http://www.foysbbq.com/

Processing: sauces

\section{Dessert Innovations}

25-B Enterprise Blvd

Atlanta, GA 30336

Phone: (800) 359-7351/(404) 691-5000

Fax: (404) 691-5001

Email: admin@dessertinnovations.com

http://dessertinnovations.com/about-us/

Processing: dessert products, truffles

\section{Dillon Candy Company}

19927 HWY 84 E

Boston, GA 31626

Phone: (800) 382-8338

Fax: (229) 498-2201

http://www.dilloncandy.com

Processing: Confections, candies

\section{Georgia Spice Company}

3600 Atlanta Industrial Parkway

Atlanta, GA 30331

Phone: (800) 453-9997

Email: SShapiro@gaspiceco.com

http://gaspiceco.com/

Processing: dry blends (dressing, drink mixes, marinades, rubs, batters, seasonings) 


\section{Hillside Orchard Farms}

18 Sorghum Mill Dr

Lakemont, GA 30552

Phone: (866) 782-4995

Email: michael@hillsideorchard.com

http://www.hillsideorchard.com

Processing: jams, jellies, dressings, sauces, juices, salsa, syrup, pickles, relish

\section{Hogwaller BBQ}

3414 Lee Rd

Hoboken, GA 31542

Phone: (912) 550-6494

Email: kennydasher@yahoo.com

https://www.hogwallerbbq.com/co-packing

Processing: sauces

\section{References and Resources}

Ahn, S., A. O'Donoughue, L. House, and R. GoodrichSchneider. 2017. How to Start a Food Business: Writing a Business Plan. FSHN14-12. Gainesville: University of Florida Institute of Food and Agricultural Sciences. https:// edis.ifas.ufl.edu/fs259.

The Association for Contract Packagers \& Manufacturers. 2018. CPA Member Directory. https:// us-tdm-tso-15eb63ff4c6-1626e-16b9f6ea201.force.com/ LightningMemberPortal/s/searchdirectory?id=a2n4P00000 $03 \mathrm{FHH}$

Brady, P. L., S. Seideman, and J. R. Morris. 2009. Choosing and Using a Co-packer. Research Report 985. Arkansas Agricultural Experiment Station. http://arkansas-ag-news. uark.edu/pdf/985.pdf

Cornell Food Venture Center. 2018. "Small Copackers \& Commercial Kitchens." https://cfvc. foodscience.cals.cornell.edu/kitchens-supplies/ small-co-packers-commercial-kitchens/

Holcomb, R. 2008. Food Processing Using a Co-packer. FAPC-106. Stillwater, OK: Oklahoma Cooperative Extension Service. http://pods.dasnr.okstate.edu/docushare/ dsweb/Get/Document-970/FAPC-106web.pdf

Hood, K. 2009. Consider a Co-packer: A Risk Management Tool. Publication 2565. Mississippi State University Extension Service. http://extension.msstate.edu/sites/default/files/ publications/publications/p2565.pdf
Rushing, J. E. 1998. Choosing and Using a Co-packer. FSE98(10-99). North Carolina State University. https:// foodprocessing.ncsu.edu/documents/entrepreneurs_copackers.pdf

Smith, D. 2014. "Preparing for High-Volume Food Product Sales: Are You Ready for a Co-packer?” Michigan State University Extension. http://www.canr.msu.edu/news/ preparing_for_high_volume_food_product_sales_are_ you_ready_for_a_co_packer

Specialty Food Co-packers Directory. 2018. http://www. specialtyfoodcopackers.com/The-Directory.html

Specialty Food Resource. 2018. “Co-packers." http:// www.specialtyfoodresource.com/get-started/ find-a-business-resource/copackers/

University of California-Davis. 2016. "California Food Processing Co-packers." http://ucfoodsafety.ucdavis.edu/ files/240926.pdf

University of Georgia Extension Food Science Outreach Program. 2016. "Suggested Contacts for Private Label Co-packing." https://www.georgia.org/sites/default/files/ wp-uploads/2016/08/Georgia-co-packers-commercialkitchens-2016-R.pdf

University of Massachusetts Extension. 2014. “Co-packers.” https://ag.umass.edu/sites/ag.umass.edu/files/food-science/ copackers_aug2014.pdf 